\title{
Regional drinking water composition effects on hip fracture risk: a spatial analysis of nationwide hospital admissions in Portugal, from 2000 to 2010
}

\section{Efeitos da composição regional da água potável no risco de fratura do fêmur: uma análise espacial das admissões hospitalares em Portugal, de 2000 a 2010}

\author{
Carla Maria Oliveira ${ }^{a, b, c}$ \\ (D) https://orcid.org/0000-0002-4594-1723 \\ E-mail: coliveiræineb.up.pt \\ Hugo Teixeirad,e \\ (D) https://orcid.org/0000-0001-8283-5826 \\ E-mail: hugi.teixeiraळgmail.com \\ Sandra Maria Alves ${ }^{a, b, c}$ \\ (iD) https://orcid.org/0000-0002-2318-7491 \\ E-mail: smfaळineb.up.pt \\ Maria Fátima Pina ${ }^{a, b, f}$ \\ (D) https://orcid.org/0000-0002-1521-7865 \\ E-mail: fatima.pina®icict.focruz.br \\ anniversidade do Porto. Instituto de Investigação e Inovação em \\ Saúde. Porto, Portugal. \\ buniversidade do Porto. Instituto de Engenharia Biomédica. \\ Porto, Portugal. \\ 'Instituto Politécnico do Porto. Escola Superior da Saúde do \\ Porto. Porto, Portugal. \\ ¿Universidade do Porto. Faculdade de Medicina. Departamento \\ de Medicina da Comunidade, Informação e Decisão em Saúde. \\ Porto, Portugal. \\ eUniversidade do Porto. Faculdade de Medicina. Centro de \\ Investigação em Tecnologias e Serviços de Saúde. Porto, \\ Portugal. \\ fFundação Oswaldo Cruz. Instituto de Comunicação e Informação \\ Científica e Tecnológica em Saúde. Rio de Janeiro, RJ, Brasil.
}

\section{Correspondence}

Carla Maria Oliveira

Universidade do Porto, Instituto de Engenharia Biomédica.

Rua Alfredo Allen, $n^{\circ}$ 208. Porto, Portugal. CEP 4200-135.

\section{Abstract}

Geographical variation on hip fractures (HF) may be related to the geographical variation of drinking water composition (DWC); minerals in drinking water may contribute to its fragility. We aim to investigate the effects of DWC on HF risk in Portugal (200o2010). From National Hospital Discharge Register we selected admissions of patients aged 50 years, diagnosed with HF caused by low/moderate energy traumas. Water components and characteristics were selected at the municipality level. A spatial generalized additive model with a negative binomial distribution as a link function was used to estimate the association of HF with variations in DWC. There were 96,905 HF (77.3\% in women). The spatial pattern of HF risk was attenuated after being adjusted for water parameters. Results show an indirect association between calcium, magnesium, and iron and HF risk but no clear relation between aluminum, cadmium, fluoride, manganese, or color and HF risk. Regarding $\mathrm{pH}$, the 6.7pH and $7 \mathrm{pH}$ interval seems to pose a lower risk. Different doseresponse relationships were identified. The increase of calcium, magnesium, and iron values in DWC seems to reduce regional HF risk. Long-term exposure to water parameters, even within the regulatory limits, might increase the regional HF risk.

Keywords:Hip Fracture; Drinking Water Composition; Hospital Admissions; Spatial Epidemiology.

1 This work had the financial support of Fundação para a Ciência e a Tecnologia (FCT/MEC) through National Funds within the framework of the project PTDC/SAU-EPI/113424/2009 and was co-financed by the FEDER via the PT2020 Partnership Agreement under the 4293 Unit I\&D. 


\section{Resumo}

A variabilidade espacial existente na fratura do colo do fêmur (FCF) pode estar relacionada com a variabilidade geográfica da composição da água para consumo (CAC), devido à ação dos minerais na fragilidade óssea. O objetivo do artigo foi investigar o efeito da CAC no risco de FCF em Portugal (2000-2010). Do registo nacional de altas hospitalares, foram selecionadas todas as admissões em indivíduos 50, com diagnóstico de FCF causado por trauma de baixo/moderado impacto. Os componentes e características da água foram usados ao nível do município. Um modelo espacial aditivo generalizado, com a distribuição binomial negativa como função de ligação, foi usado para estimar a associação de FCF e as variações da CAC. Foram selecionadas 96.905 FCF (77,3\% em mulheres). O padrão espacial de risco de FCF foi atenuado após ser ajustado pelos parâmetros da CAC. Os resultados mostraram uma associação indireta com cálcio, magnésio e ferro. No entanto, com alumínio, cádmio, fluoreto, manganês e cor, a associação com o risco não foi clara. 0 intervalo de $\mathrm{pH}$ de 6,7 a 7 parece apresentar um menor risco. Foram identificadas diferentes dose-resposta. O aumento do cálcio, magnésio e ferro na CAC parece reduzir o risco regional de FCF. Uma exposição a longo prazo, mesmo obedecendo aos limites impostos por lei, parece aumentar o risco regional de FCF.

Palavras-chave: Fractura do Colo do Fêmur; Composição de Água Potável; Admissões Hospitalares; Epidemiologia Espacial.

\section{Introduction}

Osteoporosis is a condition characterized by a low bone mineral density that increases bone fragility and consequently its susceptibility to fractures. Hip fractures (HF) are the most severe osteoporotic fractures because they require surgical treatment followed by a long recovery period with high costs to health care systems, society, and families (Aaseth; Boivin; Andersen, 2012). The risk of osteoporosis, and consequently of HF, increases exponentially with age and it is higher among women, mainly due to intense loss of bone mass after menopause. With the worldwide increasing longevity the number of HF is increasing, but with differences in trend pattern of age-standardized incidence rates between countries: a decline has been shown in regions like North America, Oceania, Northern Europe, Hong Kong, Taiwan, and in most of Central Europe; and an increase has been shown in regions like Asia, Southern Europe, and South America (Ballane et al., 2014). Additionally, differences in the spatial pattern have also been reported, with highest incidence in Scandinavia and lowest incidence in Africa. North America, Australia, and Europe (except Scandinavia) had comparable rates, while Asian regions had high variability in hip fractures rates: varying from high rates in Iran to low rates in China. Portugal is in the middle of the ranking, with an overall incidence rate lower than in the USA and northern European countries, and higher than in some Asian and other Southern European countries (Litwic et al., 2012). Although high variability between regions has been reported, high variability within regions also exists, namely in Portugal, with regions with three times more risk than others (Pina et al., 2008), some of them comparable with Scandinavian countries rates (Litwic et al., 2012; Pina et al., 2008).

The underlying causes of HF are multifactorial, although individual factors such as nutrition and physical activity play an important role; environmental and socioeconomic factors should not be disregarded. In Portugal, socioeconomic inequalities explain a small part of the spatial variability of HF risk (Oliveira et al., 2015). The role of environmental factors is still unclear, especially regarding long-term daily exposure to low doses, 
such as low doses of minerals or heavy metals by ingestion (drinking or eating) or inhalation (breathing) that can impact health. Water mineral composition is among the environmental factors that seem to be associated with osteoporosis, and long-term exposure to drinking water might be one possible reason for the geographical variation of HF incidence, although studies are still sparse and inconsistent (Dahl et al., 2013). Depending on the dose, some water components, such as aluminum or cadmium, seem to deteriorate bone health while others, such as calcium, magnesium, and manganese seem to protect it. The deposition of such minerals and metals (even in low doses) in bones, as a result of long-term exposure, might contribute to bone fragility (e.g. aluminum) or to bone resistance (e.g. magnesium and calcium) (Aaseth; Boivin; Andersen, 2012). The beneficial effect of calcium on bone mineral density is higher when in the presence of vitamin $\mathrm{D}$ rather than alone, perhaps because vitamin $\mathrm{D}$ increases calcium absorption helping to maintain parathyroid hormone (PTH) levels within the physiological limits (Aaseth; Boivin; Andersen, 2012). Iron deficiency led to a delay in collagen maturation in the femoral bones and to phosphorus-calcium metabolic disorders; magnesium is associated with regulation of calcium transport (Sojka; Weaver, 1995); and manganese can activate enzymes involved in bone metabolism (Stern, 1985), which may explain the protective effect of these elements. Aluminum is associated with reduced osteoblast activity (Monteagudo; Cassidy; Folb, 1989) and cadmium may affect calcium metabolism (Staessen, 2010), which may explain the detrimental effect of both elements to bone health. Inconsistent results have been reported regarding the effect of fluoride, suggesting that lower levels might be beneficial to bone quality by increasing the density of trabecular bone (Vestergaard et al., 1999) and by stimulating osteoblasts and inhibiting osteoclasts, while higher levels might have a toxic effect (Aaseth; Boivin; Andersen, 2012). Water characteristics such as color or $\mathrm{pH}$ may also affect bone health: higher color grades may indicate a high presence of organic matter, which promotes growth opportunities for microorganism and reduces the effectiveness of water disinfection (Dahl et al., 2013).
Besides, $\mathrm{pH}$ interferes in the toxicity of metals in water as it regulates most chemical retains and higher color grades relate to acid ( $\mathrm{pH}$ less than 7 ) and soft (low concentration of minerals) waters that usually deteriorate bone heath (Frings-Meuthen; Baecker; Heer, 2008).

Exposure to water components does not occur only by water consumption but also by using it to prepare food. Food cooked in water deficient in minerals becomes poorer than food cooked in water rich in minerals, such as magnesium (Sojka; Weaver, 1995). Distinctive regional geological conditions in Portugal (Eggenkamp; Marques, 2013) lead to differences in the composition of municipal drinking water, being one possible explanation for the high spatial variation in HF risk.

Our aim is, thus, to investigate the effects of municipality drinking water composition (DWC) on HF risk among inpatients aged 50 and older in Portugal, from 2000 to 2010.

\section{Material and methods}

\section{Study area}

The study area is Portugal, excluding the two autonomous regions - archipelagos of Azores and Madeira ( $5 \%$ of the Portuguese population) - as there were no available data on hospital admissions for them. Portugal is one of the most aged countries in Europe: in 2010, it ranked fifth in the list of the higher percentage of persons aged 65 and over, with an aging index of 120 older adults ( 65 years-old) per 100 youths (14 years-old) and $37.7 \%$ of the population older than 50 years. Recent demographic trends point to a continuous increase in life expectancy, increase in emigration and decrease in fertility rates in Portugal, thus raising the population aging index. Continental Portugal had 10,057,999 inhabitants in 2010, distributed heterogeneously throughout 278 municipalities - the least populated municipality has 1,836 inhabitants, and the most, the capital, has 548,422 inhabitants (INE - Statistics Portugal). The public water supply service is administrated by municipal and private companies and almost all (over 95\%) households are covered (Regulatory Authority of Water and Waste Services- ERSAR). 
DWC is influenced by the lithology of the soil which, in the continental territory, comprise three main groups: the acid rocks, predominant in the north region, contribute to low water mineralization; the basic rocks, predominant in the Alentejo region, contribute to medium water mineralization; and the sedimentary rocks, located mainly along the sedimentary basin of the Tejo River and the Algarve region, contribute to high water mineralization (Figure 1) (Portugal Institute of Water). The DWC differs greatly from region to region, being more calcareous and consequently having higher hardness and conductivity in the south of the country. The quality of the drinking water for human consumption in Portugal is considered excellent in almost all the territory (ERSAR).

\section{Figure I-Geographic distribution of the lithology of the soil in Continental Portugal}

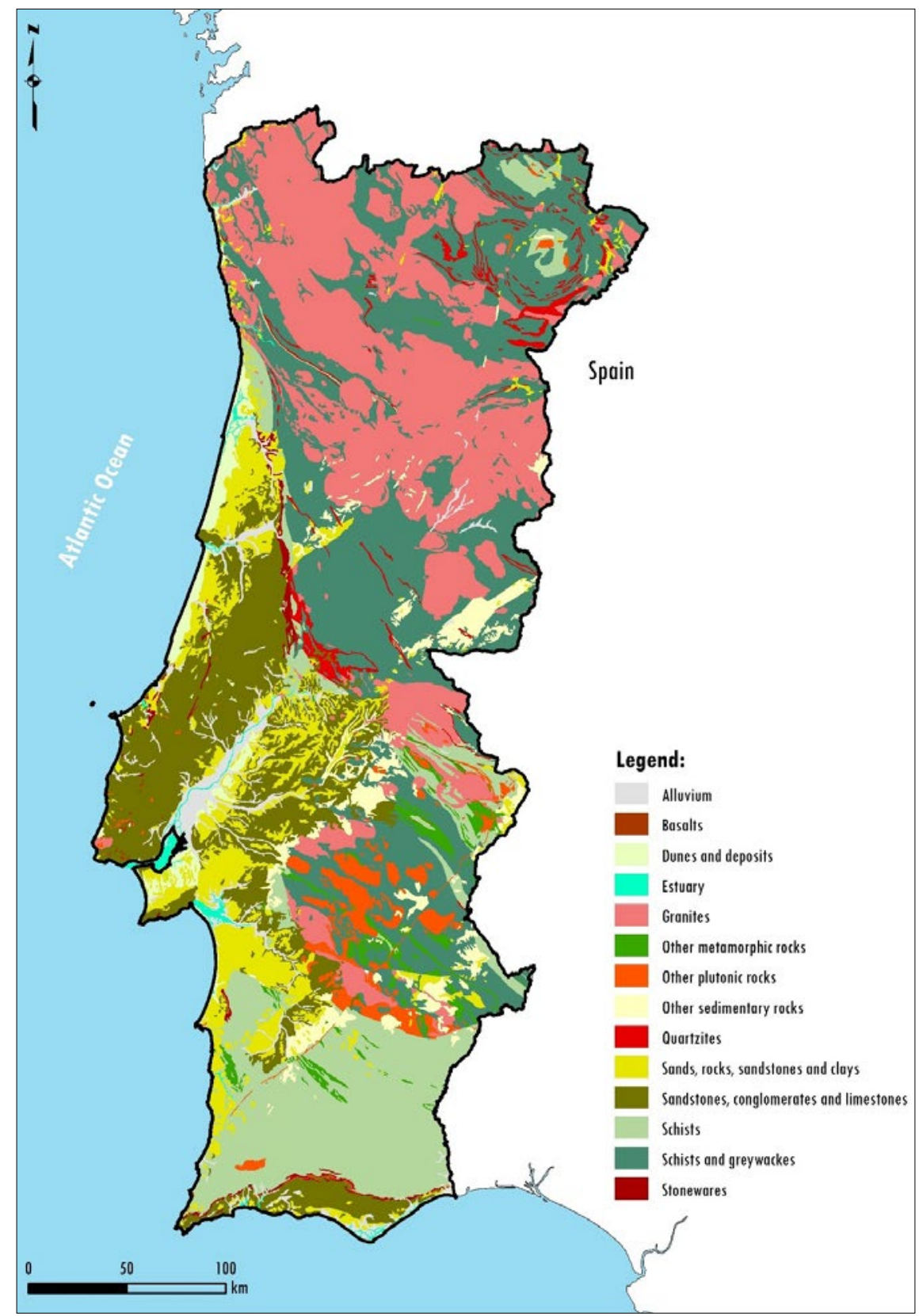


Data

This is an observational population-based ecological study using secondary data from the Portuguese National Hospital Discharge Register (NHDR). From the register, we selected all hospital admissions of patients aged 50 years or over with a discharge diagnosis of HF (ICD9-CM codes 820.x) caused by low/moderate energy trauma (ICD9-CM codes E849.o, E849.7 and E880-E888), from January 1st, 2000, to December 31st, 2010. Readmissions for aftercare (ICD9-CM codes 996.4 and $V_{54 . x)}$ and pathological fractures (ICD9-CM codes 170.x and 171.x) were excluded. More information on the NHDR can be found elsewhere (Alves et al., 2014), but briefly, since 2000 it is a compulsory system for all public hospitals, containing patients demographic and clinical data - each register corresponds to one discharge. We aggregated data by the municipality of the patient's residence, admission year, sex, and 5 -year age groups $\left(50-54, \ldots 80-84,85^{+}\right)$. The same age groups were used to aggregate counts of population, by sex and municipality. We used official population data from the Statistics Portugal (INE) - census data for the year 2001 and annual official estimates for inter-census years.

Physical and chemical parameters of municipal DWC were obtained from the ERSAR. DWC data were available by the municipality for 2011 and 2012, and values correspond to the median of one-year samples, for each component. We considered the mean values of the two available years. The decision to include water components in the analysis was based on its potential relation to bone health, according to literature review (Castiglioni et al., 2013); we included aluminum, cadmium, calcium, fluoride, iron, magnesium and manganese. We also analyzed drinking water proprieties such as color or $\mathrm{pH}$. The censored values were set at the highest detection limit values (e.g.,

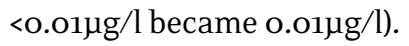

We considered land occupation for each municipality according to the classification suggested by Statistics Portugal: rural, urban, and semi-urban. Socioeconomic characterization of municipalities was calculated by principal component analysis based on a set of variables from the 2001 Census, followed by hierarchical cluster analysis; more detail about the method can be found elsewhere (Oliveira et al., 2015).

\section{Statistical analysis}

We used a spatial generalized additive model with a negative binomial distribution as a link function to estimate the relative risk (RR) of HF associated with variations in DWC, and the corresponding 95\% confidence intervals (CIs). Age group, socioeconomic status, and rural conditions were included in the model to allow (possible) different HF behavior between the various categories. The centroid (geometric center) coordinates of each municipality and the year of HF occurrence were also included in the model to account for possible spatial and time trends in HF risk.

We assumed that the number of HF, NFrat ${ }_{\text {sijt }}$, in a specific sex $s=1,2$, age group $i=1, \ldots, 8$, municipality $\mathrm{j}=1, \ldots, 278$ and year $\mathrm{t}=2000, \ldots, 2010$ is distributed as a negative binomial random variable with mean $\lambda_{\text {sijt }}=$ NFrat $_{\text {sijt }} \varrho_{\text {sijt }}$ and a scale parameter $\theta$ to allow for overdispersion (excess variation regarding a Poisson model). $\mathrm{NPop}_{\text {sijt }}$ is the population (in unit of 100,0oo) in each sex $s$, age group i, municipality j, and year t and $\varrho_{\text {sijt }}$ is the HF rate per 100,00o population in each sex $s$, age group i, municipality j, and year t. The parameters of interest were estimated based on the following complete model or in a subset of the complete model, as appropriate:

$$
\begin{aligned}
& N_{F r a t}{ }_{i t j} \sim N e g B i n\left(\lambda_{i j t}, \theta\right) \\
& \log \left(\lambda_{s i j t}\right)=\log \left(N P_{o p} p_{s j t}\right)+\beta_{0}+\beta_{1} \operatorname{Sex}_{s}+\beta_{2} A g G r_{i} \\
& +\beta_{3} S E S_{j}+\beta_{4} R_{u r U r b_{j}}+ \\
& +s_{1}\left(\text { Year }^{(t)}\right)+s_{2}\left(\operatorname{Lon}^{(j)}, \operatorname{Lat}^{(j)}\right) \\
& +s_{1}\left(\operatorname{Alum}^{(j)}\right)+s_{1}\left(\mathrm{Cad}^{(j)}\right)+s_{1}\left(\mathrm{Cal}^{(j)}\right)+ \\
& +s_{1}\left(\operatorname{Cor}^{(j)}\right)+s_{1}\left(F l u^{(j)}\right)+s_{1}\left(\operatorname{Iron}^{(j)}\right) \\
& +s_{1}\left(\operatorname{Magn}^{(j)}\right)+s_{1}\left(\operatorname{Mang}^{(j)}\right)+s_{1}\left(p H^{(j)}\right)
\end{aligned}
$$

where SES $\left(S E S_{j}\right)$, rural condition $\left(R u r U r b_{j}\right)$, centroid $\left(\operatorname{Lon}^{(j)}, \operatorname{Lat}^{(j)}\right)$ and water components such as aluminum $\left(\right.$ Alum $\left.^{(j)}\right)$, cadmium $\left(\mathrm{Cad}^{(j)}\right)$, calcium $\left(C a l^{(j)}\right)$, fluoride $\left(F l u^{(j)}\right)$, iron $\left(\right.$ Iron $\left.^{(j)}\right)$, magnesium $\left(\operatorname{Magn}^{(j)}\right)$, manganese $\left(\operatorname{Mang}^{(j)}\right)$, color $\left(\operatorname{Cor}^{(j)}\right)$ and $\mathrm{pH}$ $\left(p H^{(j)}\right)$ are parameters of the municipality j. We used two models: model 1 excludes DWC and model 2, the final model, includes all or some DWC, as appropriate. 
Non-parametric functions are one- and twodimensional smooth functions to allow for possible nonlinearities in the effect of time (year), water parameters and space (a pair of coordinates for each municipality centroid) predictors using spline functions (smoothers).

A stepwise forward regression procedure was performed starting with the basic model (model 1) and adding variables one at a time to select a final best one (model 2) with some or all DWC parameters. To compare models, we used the Akaike Information Criterion (AIC), a measure of model fit that penalizes models with too many predictors. The first DWC candidate variable to be included in model 1 was the one with the lowest AIC amongst the set of models: model 1 with the addition of a DWC. The second inclusion was performed in the same manner, and this procedure was repeated for all the different water components until we obtained the lowest possible AIC. Parameter significance for the final model was set to $5 \%$ level.

All statistical analyses were performed using the statistical software R version 2.14.1 (Project for Statistical Computing).

\section{Results}

We found 97,49o hospital admissions of patients aged 50 years or over, diagnosed with HF during the study period. We excluded 585 registers due to missing values for the municipality of residence, totaling a final sample of 96,905 ( $77.3 \%$ women) registers. Mean age (Standard Deviation - SD) at admission for women was 81.2 (8.5) years and 78.2 (10.1) years for men (t-test, p-value<0.001).

Figure 2 shows the geographic distribution of each drinking water component included in the study and the correspondent regulatory parametric limits for drinking water for human consumption in Portugal.

There is a spatial effect on HF risk and we observed changes between model 1 and model 2: the RR is lower in model 2 than in model 1 , suggesting that drinking water composition might interfere in the spatial distribution of HF risk (Figure 3). It is clear the attenuated effect on HF risk in regions around Porto (northwest) and Lisbon (central west) when including drinking water parameters in the analysis.

Figure 4 shows the effect of each municipality drinking water component on the HF risk. It seems that aluminum, cadmium, fluoride and manganese have no effect on HF risk, neither does color; values fluctuate around the mean suggesting a non-clear or non-relation between such components and HF. However, a clear dose-response relationship in the concentration of iron seems to exist: a reduction of the HF risk is observed per an increase of iron concentration. Calcium and magnesium seem to have an attenuated effect on the HF risk: as the concentration of both components increases, we observe a slight reduction of HF risk. Regarding $\mathrm{pH}$, the 6.7pH and $7 \mathrm{pH}$ interval presents a lower risk than more basic water (pH unit >7) and the 6.5-6.7pH unit. 
Figure 2 - Geographic distribution of mineral drinking water components in Continental Portugal (with the parametric limits of drinking water for human consumption)
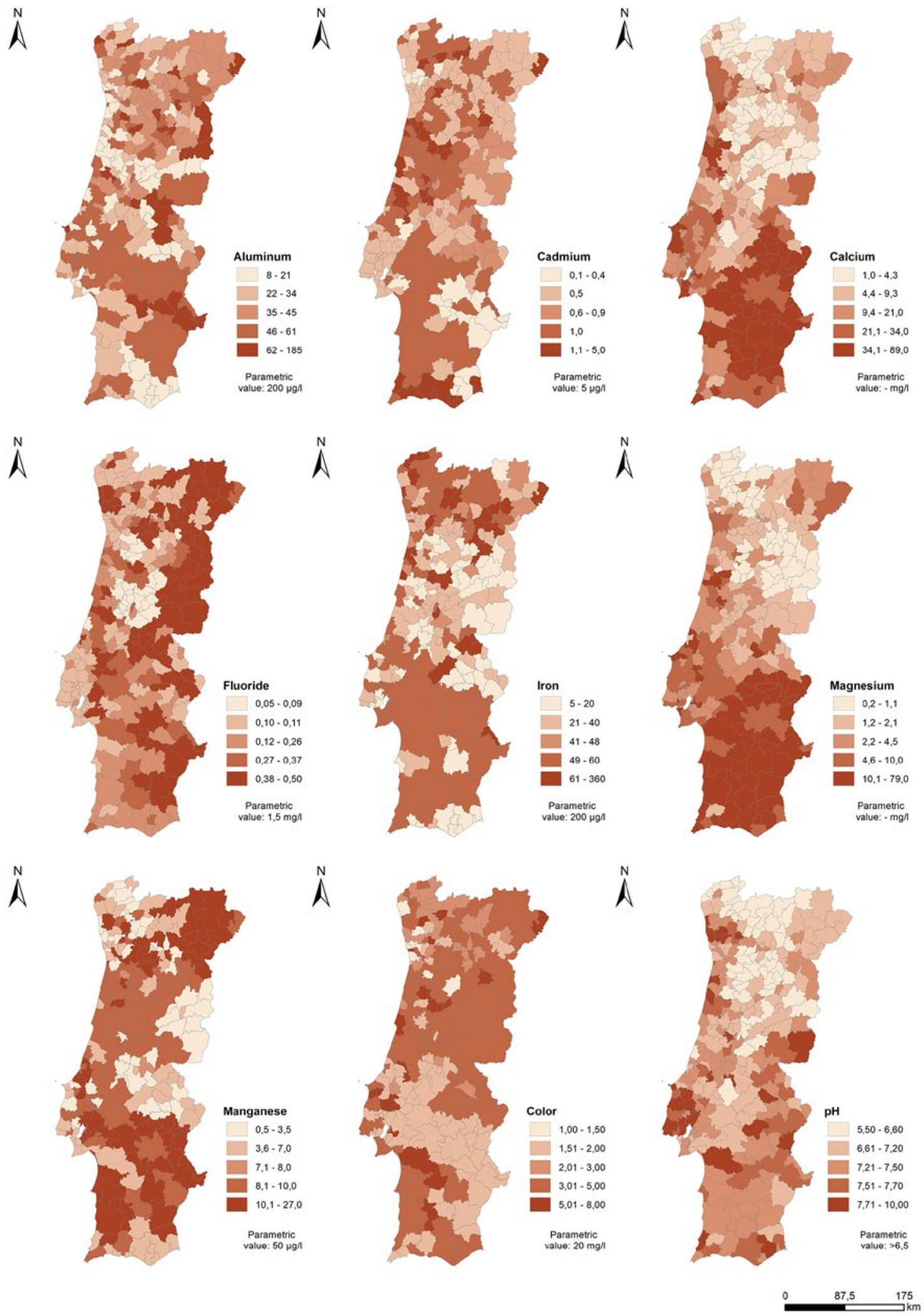
Figure 3 - Estimated spatial effect on hip fracture risk
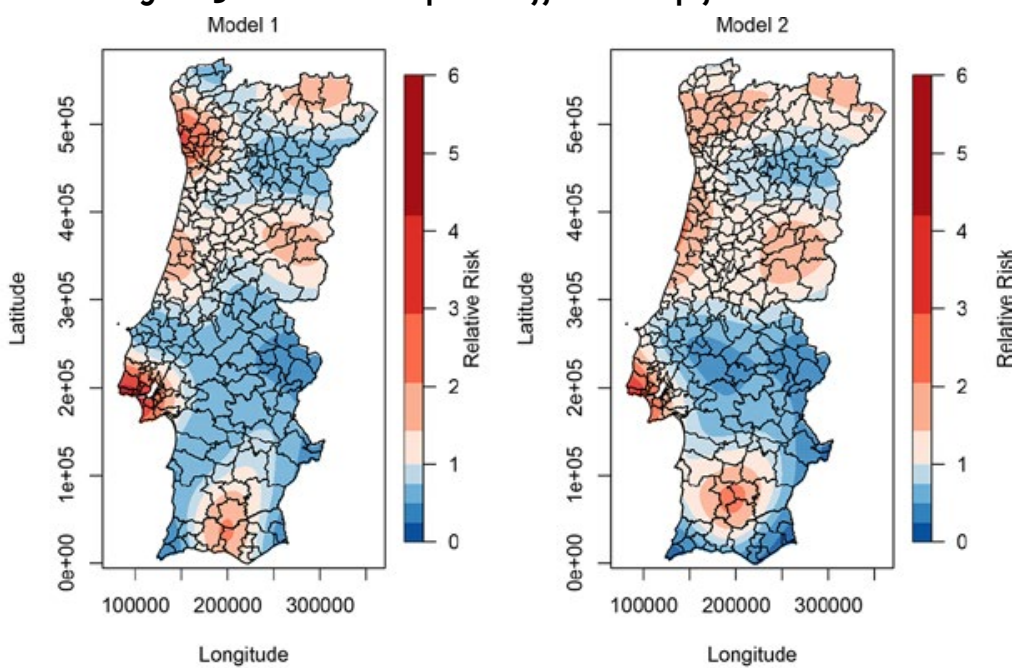

Figure 4 - Estimated drinking water composition effect on hip fracture risk and $95 \%$ confidence interval

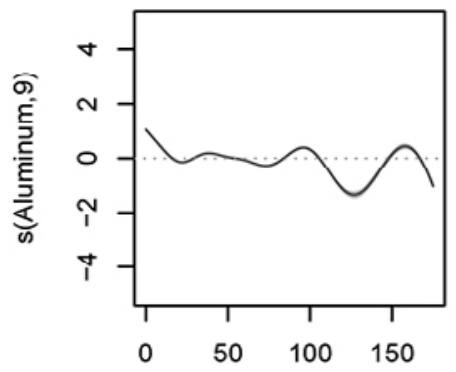

Aluminum $(\mu \mathrm{g} / \mathrm{l})$

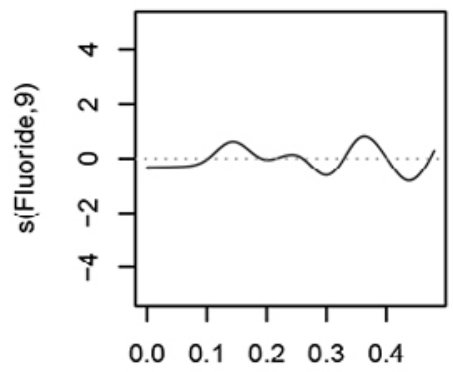

Fluoride (mg/l)

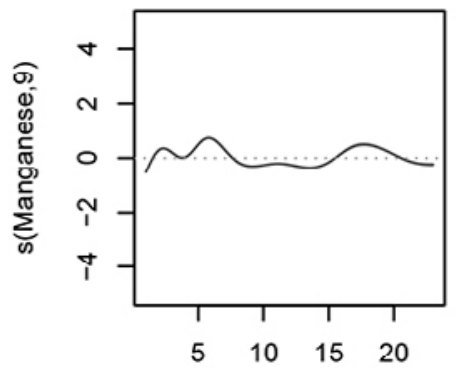

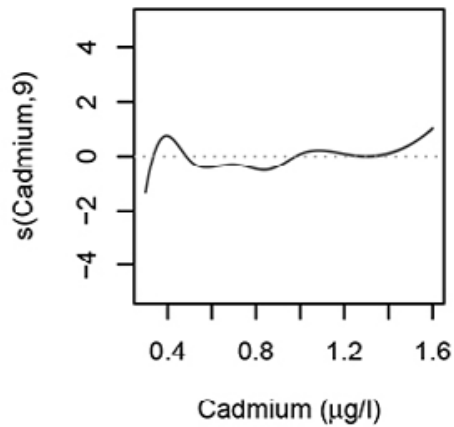
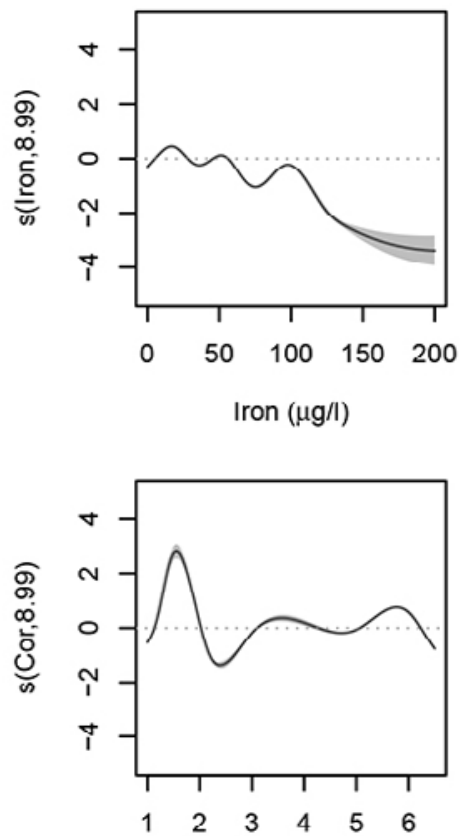
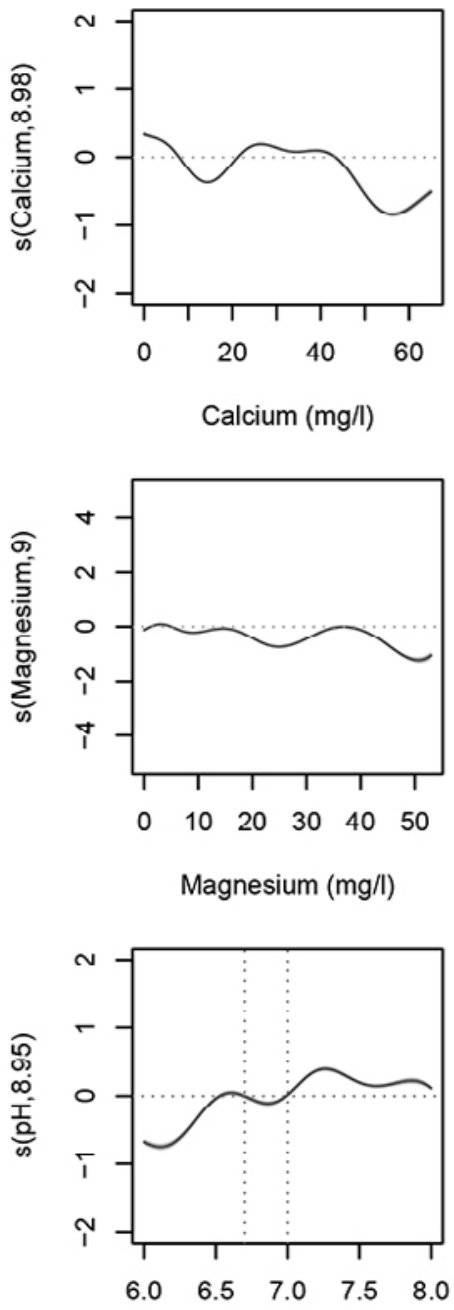


\section{Discussion}

The association between drinking water mineral composition and HF has been described in previous studies, without consensus results. Moreover, the effect of DWC on the spatial distribution of HF is not well described.

We found spatial differences in the HF risk after including DWC in the model, suggesting that municipality DWC might influence HF risk. This is biologically plausible since lifetime exposure to minerals in the drinking water may lead to a continuous mineral deposition in the bones, contributing to its fragility and consequently to increased risk of fractures. Among the water components and proprieties analyzed, associations with HF risk were found only for calcium, iron, magnesium, and some $\mathrm{pH}$ intervals.

Regarding calcium, we observe that its increasing concentration in drinking water, up to $15 \mathrm{mg} / \mathrm{l}$, is associated with a decreasing HF risk; after that threshold, the association is unclear. This inverse association between calcium concentration in the drinking water and risk of fractures might be due to the positive effect of this mineral on bone formation, shown in some studies such as in the USA (Meunier et al., 2005). Absorption and bioavailability of the calcium present in the drinking water is comparable to, or even higher than, that of the calcium present in dairy products (Bohmer; Muller; Resch, 200o); a study with participants from four centers in the USA, compared the effect of calcium by daily intake and by drinking water composition - for a 10omg dose the protective effect on bone density of calcium in the drinking water was higher than the same amount of calcium in the diet, although such differences were not statistically significant (Bauer et al., 1993). The protective effect of calcium on bone health, however, seem to be potentiated by the presence of vitamin D supplementation (Reid; Bolland; Grey, 2008), while in its absence the protective effect of calcium seems to be inhibited (Ilich; Kerstetter, 200o).

We also found an inverse association between HF risk and iron concentration in the drinking water, result compatible with the literature, which suggests that lower levels of iron might be associated with osteoporosis (d'Amelio et al., 2008); iron activates vitamin $\mathrm{D}$, affecting calcium absorption and acts as a cofactors for enzymes involved in collagen important for bone formation. On the other hand, a high iron concentration may be toxic to bone cells, contributing to osteoporosis. Nevertheless, it is unclear if the harmful effect of iron concerns the metal itself or is caused by another mechanism (Ilich; Kerstetter, 200o), as it inhibits osteoblast function through higher oxidation stress (He et al., 2013).

Our results show a decreasing HF risk per an increase of magnesium concentration, corroborating results found in Norway (Dahl et al., 2013). The influence of magnesium on fractures is unclear (Castiglioni et al., 2013), although some evidence suggest that magnesium affects parathyroid hormone (PTH) secretion and calcium homeostasis, which promotes bone formation and increases bone strength (Rude; Singer; Gruber, 2009). Magnesium insufficiency of magnesium has been associated with reduced 1.25-dihydroxyvitamin D in serum and thus reduced intestinal calcium absorption. Also, magnesium might have an anti-inflammatory effect by controlling the production of RANK-L and other mechanisms of osteoclast activation responsible for the bone reabsorption (Rude; Singer; Gruber, 2009). Studies indicate that low and high levels of magnesium might be harmful to bone health (Castiglioni et al., 2013). Our study found no high values of magnesium (above the limits defined by law as safe for human health), thus, our results reflect mainly the association with low exposure levels.

We found a lower risk of HF for $\mathrm{pH}$ between 6.7 and 7.0 than in more basic waters ( $>7 \mathrm{pH}$ unit) and between $6.5-6.7 \mathrm{pH}$. The literature associates acid waters with higher risk of HF and forearm fractures (Dahl et al., 2013). Low pH water usually contains little hydrogen, carbonate, calcium and magnesium, which are important elements to maintain bone quality. In vitro studies showed that an acid bone cell environment promotes bone resorption and the expulsion of minerals from bone cells to the exterior growth medium, result also observed in vivo studies with lower $\mathrm{pH}$ in blood being associated 
with an increase in urinary excretion of calcium and magnesium (Frings-Meuthen; Baecker; Heer, 2008).

Our results did not confirm the associations between HF risk and concentrations of aluminum, cadmium, fluoride and manganese in the drinking water, as reported in several other countries. Associations reported in the literature mainly show the harmful effect of high aluminum and cadmium concentrations on bone quality; since our samples revealed low values for these components, under the safe limits for human health, this might explain why we found no clear relation with HF risk. Fluoride is among the most studied components of drinking water since the 1960's and 1970's, when many countries adopted the fluoridation of water, mainly to improve oral health. In Portugal, water fluoridation was not an option; there was, however, an experience in fluoridation of public water supply, between 1961 and 1975 in one municipality (Montemor-o-Novo) (Duarte, 2008). Many studies analyzed the effect of exposure to fluoride in water and results are inconclusive: there is some evidence of beneficial effects of fluoride in bone health (Li et al., 2001; Vestergaard, 2008) and a direct association with HF risk such as in the USA, France, and UK (Cauley et al., 1995) while a meta-analysis relating several studies found no associations (Yin et al., 2015). In Finland, the HF risk in a region with $1 \mathrm{mg} / \mathrm{L}$ concentration of fluoride in drinking water was 50\% lower than in a region without water fluoridation; however, a further follow-up study showed that when adjusted for age and sex this effect disappeared (Alhava et al., 1980). In China, higher HF risk was observed in a population exposed to fluoride concentration levels between 1ppm and 1.06ppm (Li et al., 2001).

Less is known about the effect of manganese on drinking water and bone health. However, manganese helps synthesize mucopolysaccharides in bone matrix formation and is a cofactor for some enzymes in bone tissues, which is essential for bone quality and growth (Clegg et al., 1998). A combined manganese and calcium supplementation showed higher gain in bone quality in postmenopausal women when compared with calcium alone (Strause et al., 1994).
Our results should be interpreted with caution since limitations inherent to the study design and the available data exist. Using a national secondary data on hospital admissions that excludes registers from private hospitals could be seen as a limitation, however in Portugal the public hospitals treat almost all HF cases, thus the national discharge register can be seen as a nationwide portrait. Slow deposition of minerals in the bones due to lifetime exposure affects the relation between DWC and HF. Therefore, using a single value for each water component, corresponding to the mean of the two medians of all samples in each municipality (in 2011 and in 2012), could be an important limitation. This would be true if we were analyzing parameters of water quality, which deeply change over time; however, our analysis concerns drinking water mineral composition, which is mainly determined by the lithological and geological characteristics of the water source soil and we do not expect important changes over time at a municipal scale (Eggenkamp; Marques, 2013). As an ecological study, we are not evaluating individual exposure to DWC.

The major strengths of our study include the large-scale population-based design that allows a high statistical power able to detect small relative differences in HF and the data from nationwide registers that minimize the risk of selection and information bias. There are accentuated inequalities in the HF risk in Portugal, and we could partially explain such geographic patterns by differences in the exposure to minerals present in drinking water.

\section{Final considerations}

We found a significantly reduced risk of HF associated with higher concentration (within the regulatory limits for human consumption) of calcium, magnesium, and iron in the drinking water. We found no relation between aluminum, cadmium, fluoride and manganese concentration in the drinking water, or water color and HF risk. Our study suggests that the HF risk is lower for neutral drinking water. This study brings important insights about the influence of drinking water in the 
HF risk, but other studies are needed to clarify the associations found here. A better knowledge of the association between environmental factors and HF incidence can help better health policy decisions to prevent HF and contribute to a healthy aging.

\section{References}

AASETH, J.; BOIVIN, G.; ANDERSEN, O. Osteoporosis and trace elements--an overview. Journal of Trace Elements in Medicine and Biology, Amsterdã, v. 26, n. 2-3, p. 149-152, 2012.

ALHAVA, E. M. et al. The effect of drinking water fluoridation on the fluoride content, strength and mineral density of human bone. Acta orthopaedica Scandinavica, Lund, v. 51, n. 3, p. 413-420, 1980.

ALVES, S. M. et al. Age-period-cohort effects in the incidence of hip fractures: political and economic events are coincident with changes in risk. Osteoporosis International, Berlim, v. 25, n. 2, p. 711-720, 2014.

BALLANE, G. et al. Secular trends in hip fractures worldwide: opposing trends East versus West. Journal of Bone and Mineral Research, Washington, DC, v. 29, n. 8, p. 1745-1755, 2014.

BAUER, D. C. et al. Factors associated with appendicular bone mass in older women. The Study of Osteoporotic Fractures Research Group. Annals of Internal Medicine, Filadélfia, v. 118, n. 9, p. $657-665,1993$.

BOHMER, H.; MULLER, H.; RESCH, K. L. Calcium supplementation with calcium-rich mineral waters: a systematic review and meta-analysis of its bioavailability. Osteoporosis International, Berlim, v. 11, n. 11, p. 938-943, 2000.

CASTIGLIONI, S. et al. Magnesium and osteoporosis: current state of knowledge and future research directions. Nutrients, Basileia, v. 5, n. 8, p. 3022-3033, 2013.

CAULEY, J. A. et al. Effects of fluoridated drinking water on bone mass and fractures: the study of osteoporotic fractures. Journal of Bone and Mineral Research, Washington, DC, v. 10, n. 7, p. 1076-1086, 1995.

CLEGG, M. S. et al. The influence of manganese deficiency on serum IGF-1 and IGF binding proteins in the male rat. Experimental Biology and Medicine, Thousand Oaks, v. 219, n. 1, p. 41-47, 1998.

D'AMELIO, P. et al. Role of iron metabolism and oxidative damage in postmenopausal bone loss. Bone, Amsterdã, v. 43, n. 6, p. 1010-1015, 2008.

DAHL, C. et al. Nationwide data on municipal drinking water and hip fracture: could calcium and magnesium be protective? A NOREPOS study. Bone, Amsterdã, v. 57, n. 1, p. 84-91, 2013.

DUARTE, M. E. Os fluoretos na água de consumo humano. Setúbal: Ministério da Saúde, 2008.

EGGENKAMP, H. G. M.; MARQUES, J. M. A comparison of mineral water classification techniques: occurrence and distribution of different water types in Portugal (including Madeira and the Azores). Journal of Geochemical Exploration, Amsterdã, v. 132, p. 125-139, 2013.

FRINGS-MEUTHEN, P.; BAECKER, N.; HEER, M. Low-grade metabolic acidosis may be the cause of sodium chloride-induced exaggerated bone resorption. Journal of Bone and Mineral Research, Washington, DC, v. 23, n. 4, p. 517-524, 2008.

HE, Y. F. et al. Iron overload inhibits osteoblast biological activity through oxidative stress.

Biological trace element research, Berlim, v. 152, n. 2, p. 292-296, 2013.

ILICH, J. Z.; KERSTETTER J. E. Nutrition in bone health revisited: a story beyond calcium. Journal of the American College of Nutrition, Clearwater, v. 19, n. 6, p. 715-737, 2000.

LI, Y. et al. Effect of long-term exposure to fluoride in drinking water on risks of bone fractures. Journal of Bone and Mineral Research, Washington, DC, v. 16, n. 5, p. 932-939, 2001.

LITWIC, A. et al. Geographic differences in fractures among women. Womens Health, Londres, v. 8, n. 6, p. 673-684, 2012.

MEUNIER, P. J. et al. Consumption of a high calcium mineral water lowers biochemical indices of bone remodeling in postmenopausal women with low calcium intake. Osteoporosis International, Berlim, v. 16, n. 10, p. 1203-1209, 2005.

MONTEAGUDO, F. S.; CASSIDY, M. J.; FOLB, P. I. Recent developments in aluminum toxicology. 
Medical Toxicology and Adverse Drug Experience, [S.l.], v. 4, n. 1, p. 1-16, 1989.

OLIVEIRA, C. M. et al. The interactions between municipal socioeconomic status and age on hip fracture risk. Osteoporosis International, Berlim, v. 26 , n. 2, p. 489-498, 2015.

PINA, M. F. et al. Hip fractures cluster in space: an epidemiological analysis in Portugal. Osteoporosis International, Berlim, v. 19, n. 12, p. 1797-1804, 2008.

REID, I. R.; BOLLAND, M. J.; GREY, A. Effect of calcium supplementation on hip fractures. Osteoporosis International, Berlim, v. 19, n. 8, p. 1119-1123, 2008.

RUDE, R. K.; SINGER, F. R.; GRUBER, H. E. Skeletal and hormonal effects of magnesium deficiency. Journal of the American College of Nutrition, Clearwater, v. 28, n. 2, p. 131-141, 2009.

SOJKA, J. E.; WEAVER, C. M. Magnesium supplementation and osteoporosis. Nutrition reviews, Oxônia, v. 53, n. 3, p. 71-74, 1995.
STAESSEN, J. A. et al. Environmental exposure to cadmium, forearm bone density, and risk of fractures: prospective population study. Public Health and Environmental Exposure to Cadmium (PheeCad) Study Group. Lancet, Londres, v. 353, n. 9159, p. 1140-1144, 1999.

STERN, P. H. Biphasic effects of manganese on hormone-stimulated bone resorption. Endocrinology, Oxônia, v. 117, n. 5, p. 2044-2049, 1985.

STRAUSE, L. et al. Spinal bone loss in postmenopausal women supplemented with calcium and trace minerals. Journal of Nutrition, oxônia, v. 124, n. 7, p. 106o-1064, 1994.

VESTERGAARD, P. et al. Effects of treatment with fluoride on bone mineral density and fracture risk--a meta-analysis. Osteoporosis International, Berlim, v. 19, n. 3, p. 257-268, 2008.

YIN, X. H. et al. Exposure to fluoride in drinking water and hip fracture risk: a meta-analysis of observational studies. PLOS ONE, São Francisco, v. 10, n. 5, p. e0126488, 2015.

\section{Acknowledgments}

We acknowledge the Central Administration of Health Services (ACSS) for the data from the National Hospital Discharge Register.

\section{Authors' contribution}

Oliveira designed the study; prepared, analyzed and interpreted the data; discussed, wrote and revised the manuscript. Teixeira prepared and analyzed the data. Alves interpreted the data; discussed and revised the manuscript. Pina designed and supervised the study; interpreted the data; discussed, wrote and revised the manuscript.

Received: 10/05/2020

Approved: 02/06/2020 